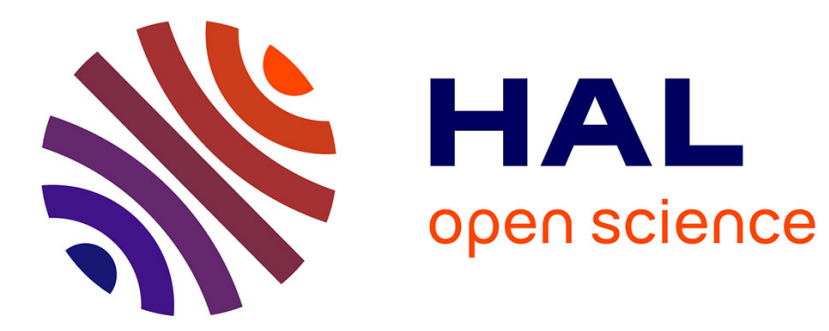

\title{
Effect of season and age on Indian red jungle fowl (Gallus gallus murghi) semen characteristics: A 4-year retrospective study
}

\author{
B.A. Rakha, M.S. Ansari, S. Akhter, Elisabeth Blesbois
}

\section{- To cite this version:}

B.A. Rakha, M.S. Ansari, S. Akhter, Elisabeth Blesbois. Effect of season and age on Indian red jungle fowl (Gallus gallus murghi) semen characteristics: A 4-year retrospective study. Theriogenology, 2017, 99, pp.105-110. 10.1016/j.theriogenology.2017.05.016 . hal-01603284

\section{HAL Id: hal-01603284 \\ https://hal.science/hal-01603284}

Submitted on 26 May 2020

HAL is a multi-disciplinary open access archive for the deposit and dissemination of scientific research documents, whether they are published or not. The documents may come from teaching and research institutions in France or abroad, or from public or private research centers.
L'archive ouverte pluridisciplinaire HAL, est destinée au dépôt et à la diffusion de documents scientifiques de niveau recherche, publiés ou non, émanant des établissements d'enseignement et de recherche français ou étrangers, des laboratoires publics ou privés. 


\section{Accepted Manuscript}

Effect of season and age on Indian red jungle fowl (Gallus gallus murghi) semen characteristics: A 4-year retrospective study

B.A. Rakha, M.S. Ansari, S. Akhter, E. Blesbois

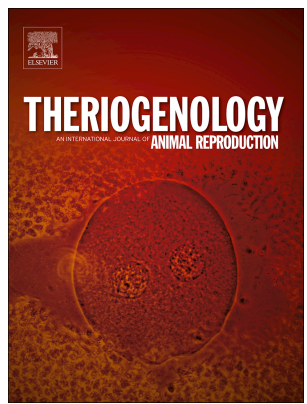

PII:

S0093-691X(17)30255-8

DOI:

10.1016/j.theriogenology.2017.05.016

Reference: THE 14121

To appear in: Theriogenology

Received Date: 19 December 2016

Revised Date: 21 May 2017

Accepted Date: 21 May 2017

Please cite this article as: Rakha BA, Ansari MS, Akhter S, Blesbois E, Effect of season and age on Indian red jungle fowl (Gallus gallus murghi) semen characteristics: A 4-year retrospective study, Theriogenology (2017), doi: 10.1016/j.theriogenology.2017.05.016.

This is a PDF file of an unedited manuscript that has been accepted for publication. As a service to our customers we are providing this early version of the manuscript. The manuscript will undergo copyediting, typesetting, and review of the resulting proof before it is published in its final form. Please note that during the production process errors may be discovered which could affect the content, and all legal disclaimers that apply to the journal pertain. 
1

2

6

$7{ }^{1}$ Department of Wildlife Management, Pir Mehr Ali Shah Arid Agriculture University

8 Rawalpindi-46300, Pakistan

$9{ }^{2}$ Department of Zoology, University of Sargodha, Lyallpur Campus, Faisalbad-38000, 10 Pakistan

$11{ }^{3}$ Department of Zoology, Pir Mehr Ali Shah Arid Agriculture University Rawalpindi-46300,

Original Research Paper
Effect of season and age on Indian red jungle fowl (Gallus gallus murghi) semen characteristics: A 4-year retrospective study
B. A. Rakha ${ }^{1}$, M. S. Ansari ${ }^{2}$, S. Akhter ${ }^{3}$, and E. Blesbois ${ }^{4}$

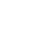

\section{Pakistan}

${ }^{4}$ INRA, UMR85 Physiologie de la Reproduction et des Comportements, F-37380 Nouzilly, 37380, Nouzilly, France

Running Title: Effect of season and age on semen characteristics of Indian Red Jungle Fowl

"Corresponding Author:

Bushra Allah Rakha

Department of Wildlife Management

Pir Mehr Ali Shah, Arid Agriculture University, Rawalpindi-46300, Pakistan

Mobile: +92-300-2020625

Email: bushrauaar@gmail.com 


\section{ABSTRACT}

The reproductive potential of the adult males is expected to vary with age/season and largely differ not only in closely related avian species but even in subspecies, breeds and/or strains of the same species. Thus, it is pre-requisite to have knowledge of seminal parameters to achieve maximum production potential of at-risk species for ex situ in vitro conservation programs. A 4-year study was designed to evaluate the effect of age and season (spring, summer, autumn and winter) on semen characteristics of Indian red jungle fowl (Gallus gallus murghi) in retrospective manner. Semen ejaculates $(\mathrm{n}=1148)$ were regularly collected from eight adult Indian red jungle fowls from 6 to 54 months of age. Quantitative and qualitative semen parameters viz; volume $(\mu \mathrm{L})$, concentration $\left(1 \times 10^{9} \mathrm{~mL}^{-1}\right)$, total sperm number per ejaculate $\left(1 \times 10^{9} \mathrm{~mL}^{-1}\right)$, motility (\%), viability (\%), plasma membrane integrity $(\%)$, acrosome integrity $(\%)$ and semen quality factor were recorded. A chronological increasing trend with age of most sperm quantitative and qualitative traits (semen volume, sperm concentration, total sperm number per ejaculate, plasma membrane integrity, viability, acrosomal integrity, semen quality factor) was observed. The highest values were observed at four years of age $(\mathrm{P}<0.05)$ with the exception of sperm motility that was not affected by the age. Spring was the best season for sperm parameters viz; volume, motility, plasma membrane integrity, viability and acrosomal integrity $(\mathrm{P}<0.05)$, however a remarkable sperm production was noticed all over the year. It is concluded that Indian red jungle fowl exhibit an evolution of sperm production that greatly differs in many points from other fowl sub-species. It is suggested that semen ejaculates of highest quality achieved for semen banking at the age of four year in the spring season.

Keywords: Semen characteristics; Age; Season; Quantitative semen quality; Qualitative semen quality; Indian red jungle fowl 


\section{Introduction}

The red jungle fowl, a member of family Phasianidae and genus Gallus is considered one of the ancestors of the domestic fowl [1-3]. The red jungle fowl is enlisted as least concern species in IUCN Red List of Threatened Species [4] but its population is continuously declining in its native habitat $[2,5]$. Red jungle fowl is considered as endangered in Singapore list of Threatened Plant and Animal Species, facing high risk of extinction in the wild [6]. From five fowl subspecies, Indian red jungle fowl (Gallus gallus murghi) is native to Northern India and Azad Jammu and Kashmir, Pakistan [7-10]. The Indian red jungle fowl population is found in restricted areas in fragments, and is more likely to collapse of genetic diversity and population decline due to sudden unexpected threats [2,11-13]. The factors contributing in population reduction are habitat destruction, egg collection, predation and genetic hybridization with domestic fowl $[7,13]$.

The decline in Indian red jungle fowl needs special attention; several reports suggest adopting appropriate ex situ conservation strategies [2,11,12]. For ex situ in vitro conservation, semen banking is considered one of the most applicable options for bird species that are facing continuous decline in their natural habitat and the threats cannot be easily mitigated and/or ameliorated [14-20]. Cryo-banking of valuable male germplasm could be an important assisted reproductive biotechnology to maintain genetic diversity and in vitro ex situ conservation program $[8,9]$. It is well established that avian semen can be stored in frozen state for infinite period of time without significant decline in fertilizing potential $[17,21,22]$. The characteristics of the semen ejaculate viz; volume, concentration, motility, viability, plasma membrane and acrosome integrity, semen quality factor determine the reproductive potential of the cocks either used in natural or artificial breeding program [8,9,23-25]. Nevertheless, semen quality varies with age and season of collection in birds that may affect fertilizing capacities accordingly [26-28]. The success of semen banking depends 
on successful cryopreservation and acceptable frozen thawed semen quality and fertility outcomes that depend on the initial quality of the ejaculate to be used in processing for cryopreservation $[17,20,29]$. The reproductive performance of the male fowl varies with age and seasons; largely differ not only in closely related bird species but also even in subspecies, breeds and/or strains of the same species [30]. Scarce available literature depicted immense variations in semen characteristics of five subspecies of red jungle fowl [8,31]. The knowledge about retrospective seminal parameters is therefore the perquisite to achieve maximum production potential of at-risk species for ex situ in vitro conservation.

Therefore, present, 4-year retrospective study was designed to elucidate the effect of age and season (autumn, spring, summer and winter) on semen characteristics (motility, semen volume, sperm concentration, total sperm number per ejaculate, viability, semen quality index, plasma membrane and acrosome integrity) of Indian red jungle fowl.

\section{Materials and methods}

\subsection{Experimental birds}

The chicks of Indian red jungle fowl were reared at Avian Research Center, Pir Mehr Ali Shah Arid Agriculture University Rawalpindi. The Rawalpindi region (33 $36^{\prime} 0^{\prime \prime}$ North, $73^{\circ} 4^{\prime} 0^{\prime \prime}$ East) is located in Southern slopes of the North-Western Himalayas including large mountain tracks with rich valleys traversed by mountain rivers. This region falls in humid and subtropical region having four seasons; autumn $\left(13.9^{\circ} \mathrm{C}\right.$ to $\left.33.5^{\circ} \mathrm{C}\right)$, spring $\left(10.1^{\circ} \mathrm{C}\right.$ to $\left.23.7^{\circ} \mathrm{C}\right)$, summer $\left(21.5^{\circ} \mathrm{C}\right.$ to $\left.46.5^{\circ} \mathrm{C}\right)$ and winter $\left(-2.8^{\circ} \mathrm{C}\right.$ to $\left.20.0^{\circ} \mathrm{C}\right)$. The average annual rainfall of this region is about 1,249 millimeters. The average rainfall in each season was $73.13 \mathrm{~mm} /$ autumn, $39.2 \mathrm{~mm} /$ spring, $224.73 \mathrm{~mm} / \mathrm{summer}$ and $37.3 \mathrm{~mm} /$ winter recorded during the study period. The average temperature of the area ranges from $-3.9^{\circ} \mathrm{C}$ to $48.3^{\circ} \mathrm{C}$ (Pakistan Metrological Department, 2012-2015). The chicks were kept in individual pens 
101

102

103

104

105

106

107

108

109

110

111

112

113

114

115

116

117

118

119

120

121

122

123

124

$106.68 \mathrm{~cm} \times 121.92 \mathrm{~cm}$, exposed to natural day-light and standardized environmental conditions without any significant changes during the entire 4-year study period. The birds were offered commercially available poultry cock breeder feed (100g/day). Fresh water was available to the birds all the daylong throughout the experimental period. The birds were subjected to abdominal massage and were trained for semen collection until the birds were able to donate neat and clean semen without fecal contamination. This training was continued until we were able to get sufficient semen for further processing and experimental work. Semen collection of eight cocks was performed on alternate days, depending on individual cock quality and libido.

\subsection{Semen collection and quantitative evaluation}

The birds were subjected to semen collection training through abdominal massage as described by Burrows and Quinn [8, 32,33]. The successful ejaculate was collected after 4 weeks of training. Semen was collected from individual birds in a graduated plastic tube. A total of 1148 ejaculates were studied during the 4-year study period (2012-2015). Semen volume was measured in microlitres using micropipette.

\subsubsection{Sperm progressive motility}

Sperm motility of each ejaculate was determined as described by Zemjanis [34] by mixing $10 \mu \mathrm{L}$ of semen samples in $500 \mu \mathrm{L}$ of phosphate buffer saline $(\mathrm{pH} 7.2,300$ $\mathrm{mOsm} / \mathrm{kg}$ ). The percentage of motile sperm was subjectively evaluated on a scale ranging from 0 to $100 \%$ by putting a drop of semen sample on a pre-warmed glass slide $\left(37^{\circ} \mathrm{C}\right)$ under phase contrast microscope (x400, Olympus BX20, Japan).

\subsubsection{Sperm concentration}

Sperm concentration was measured by taking $1 \mu \mathrm{L}$ of semen and $200 \mu \mathrm{L}$ of formal citrate solution ( $1 \mathrm{~mL}$ of $37 \%$ formaldehyde in $99 \mathrm{~mL}$ of $2.9 \%(\mathrm{w} / \mathrm{v})$ sodium citrate) with 
Neubauer haemocytometer (Marienfeld, Germany) under phase contrast microscope (x400,

Olympus BX20, Japan) throughout the 4-year study period [8].

127

\subsubsection{Total sperm number per ejaculate}

Total sperm number per ejaculate was obtained by multiplying the total volume with the concentration of ejaculates obtained during the study period $[8,35]$.

\subsubsection{Plasma membrane integrity}

Plasma membrane integrity of spermatozoa was assessed by using hypo-osmotic swelling test (HOS) as described by Santiago-Moreno et al. [36]. The HOS solution was prepared by adding $1 \mathrm{~g}$ of sodium citrate to $100 \mathrm{~mL}$ of distilled water. Semen $(25 \mu \mathrm{L})$ was mixed with $500 \mu \mathrm{L}$ of HOS solution $(100 \mathrm{mOsm} / \mathrm{kg})$ and incubated at $37^{\circ} \mathrm{C}$ for 30 minutes. A drop of incubated solution was placed on a pre warmed $\left(37^{\circ} \mathrm{C}\right)$ slide and fixed in buffered $2 \%$ glutaraldehyde. The spermatozoa showing swollen heads, swollen and coiled tails were classified as normal spermatozoa having intact plasma membrane. A total of 200 spermatozoa were counted at four separate fields under a phase-contrast microscope (1000x with oil immersion).

\subsubsection{Sperm viability}

Viability (\% Live / total sperm) of Indian Red Jungle Fowl spermatozoa was examined by adding eosin-nigrosin to the lake glutamate solution [37]. Twelve drops of stain were mixed with 1 drop of semen. A smear was made on a glass slide, fixed and air dried. A total of 200 spermatozoa were studied per slide under a phase-contrast microscope (1000x with oil immersion). The mixture provides a clear background in the smear to enhance the contrast of white and pink. Unstained and straight sperm were considered as "live and morphologically normal" while the pinkish stained as "dead" sperm.

\subsubsection{Acrosomal integrity}


Giemsa stain [38]. The stain was prepared by adding Giemsa (3g) and phosphate buffer saline a clean glass slide, dried and fixed in neutral formal-saline (5\% formaldehyde) for $30 \mathrm{~min}$. Fixed slides were kept in Giemsa stain for $1.5 \mathrm{hrs}$. Sperm with normal acrosome appeared to be evenly stained; abnormal spermatozoa were unevenly stained while spermatozoa having ruptured acrosome remained unstained. A total of 200 spermatozoa were observed at least in four separate fields under a phase-contrast microscope (x400; Olympus BX20, Japan) at magnification of $1000 \mathrm{x}$ with oil immersion.

\subsubsection{Sperm quality factor}

Sperm quality factor (SQF) of each semen ejaculate was calculated to check the

number of spermatozoa potentially capable of fertilization in ejaculate. Sperm quality factor

was calculated by the following formula [24].

$\mathrm{SQF}=\frac{\text { Sperm concentration }\left(\frac{\text { billion }}{\mathrm{mL}}\right) \times \text { ejaculate volume }(\mathrm{mL}) \times \text { normal livespermatozoa }}{100}$

163

164

165

166

167

168

169

170

\subsection{Statistical analysis}

The data were analyzed with statistical software Megastat ${ }^{\circledR}$ version 7.25 Mc-Graw-Hill New Media, New York, for excel. The descriptive statistical parameters (mean, standard error of mean) were calculated for different age groups and seasons. To compare differences between seasons and age groups, data were analyzed using analysis of variance in completely randomized design with unequal replications. Post hoc comparisons between the means were done though least significant difference test to determine differences among individual groups at different ages and seasons. Differences were considered statistically different when $\mathrm{P}<0.05$, and presented as Mean $\pm \mathrm{SEM}$. 


\section{Results}

The data on ejaculate volume, sperm concentration and total sperm number per ejaculate of red jungle fowl from 6 to 54 months of age are given in Table 1. Semen volume, sperm concentration and total sperm number per ejaculate was recorded significantly $(\mathrm{P}<0.05)$ higher at 43-54 months of age followed by 31-42, 19-30 and 6-18 months of age. The highest $(\mathrm{P}<0.05)$ semen ejaculate volume, sperm concentration and total sperm number were recorded in spring season followed by winter, autumn and summer from 6 to 54 months of age.

The data on qualitative semen quality parameters viz; motility, plasma membrane integrity, viability, acorosme integrity and semen quality factor were given in Table 2 . Sperm motility did not differ $(\mathrm{P}>0.05)$ with increase in age from 6 to 54 months of age. Nevertheless, an increase was observed in plasma membrane integrity, viability, acrosome integrity and semen quality factor with the increasing age. The highest $(\mathrm{P}<0.05)$ values for aforementioned parameters were recorded during 43-54 months of age compared to 31-42, 19-30 and 6-18 months of age. A highly positive $(\mathrm{P}<0.05)$ effect of spring season was recorded on most of the quality parameters with the exception of motility that was equivalently efficient in autumn, spring and summer and only altered in winter.

\section{Discussion}

In conservation programs, the success of $\mathrm{AI}$ and semen cryopreservation depends on the initial semen quality of ejaculate [17]. Semen evaluation, based on in vitro measurement of sperm motility, plasma membrane integrity, viability, acrosomal integrity and semen quality factor (SQF) provides an indirect clue about the fertility potential of the males $[25,8,23,24]$. The production of high quality semen ejaculates depends on the reproductive cycle of the species; furthermore, species or subspecies specific variations depend on the birds, their age, their environment including climate changes such as seasons [30, 36,39-46]. 
In contrast to domestic fowl, we showed for the first time in the present study that the highest production and quality of semen of Indian red jungle fowl is not reached until the fourth year of age and spring stays the best season.

Our results greatly differ from the observations made in most domestic fowl as Long et al. [47] reported a decrease in sperm concentration from 1 to 1.5 years of age, a wellknown fact in the breeding practice. Nevertheless, this situation would be modulated in local breeds of tropical area as Chotesangasa [48] and Sonseeda et al. [45] found an increase in Thai indigenous chicken sperm concentration between 1 and 2 years of age. However, our results with Indian red jungle fowl appeared to be "extreme" as 4 years of age is the best in terms of sperm concentration and volume. Semen volume has already been reported to differ with the age in Leghorns [30]. Contrary to our findings, broiler males showed maximum semen volume in the first year of age and then decreased with age, a difference with here, one of the presumed ancestors, the red jungle fowl. As a way of consequence, the total number of sperm per ejaculate increased with the age, and was observed highest when the Indian red jungle fowls were 4 years old. This leads to suggest an increase in the efficiency of sperm production with the age in this wild fowl. Many hypotheses may arise from this observation including suggestion of increasing adaptation of the species to its environment, nutrition, and management conditions. However, due to low mean volume of semen, total sperm number per ejaculate (billion) were still lower in Indian red jungle fowl compared to Malaysian red jungle fowl [31] and domestic fowls [47,49]. Would there be a sort of "compensation" of this low daily sperm production through and increasing of the longevity of sperm production?

In addition to the increase of sperm production with the age, it was evident that the functionality of the sperm produced by Indian red jungle fowl increased with the age to reach a maximum at 4 years as most of the quality parameter measured here (Hypo-osmotic test, livability, acrosome integrity) were at their optimum at 43-54 months of age. 
More precisely, Indian red jungle fowl spermatozoa showed greater resistance to the

224

hypo-osmotic solution at $37^{\circ} \mathrm{C}$ at 4 years of age. These changes would indicate that sperm plasma membrane increases its "plasticity" with the age and thus its functionality. Indeed, the response of spermatozoa towards hypo-osmotic solution in terms of swollen head and coiled tail is due to the movement of physical and biochemical compounds which play essential roles in maintaining the viability and fertilizing ability of sperm [50-52]. Shanunagum et al. [44] reported that response of spermatozoa to the hypo-osmotic environment at one year of age was maximum compared to 6 months of age; and described that age and genetic factors contribute to the quality of semen in naked neck and dwarf chicken. But none of these studies examined 3 or 4 years old fowl, thus limiting the potential comparison with our study.

Sperm viability and the integrity of the sub-cellular fraction of sperm such as the acrosome are of absolute significance for the success of fertilization. In the present study, viability and acrosome integrity were highest at the age of 43-54 months, a fact that is opposite to the results described in previous reports. Indeed, decreases in viability and sperm morphological integrity have previously been reported to coincide with the end of a reproductive period between 1 and 1.5 years of age in free-range poultry [44], turkeys [53] and roosters $[54,55]$. Such decrease has been related to changes in lipid composition and decrease in fertility [55]. However, for these parameters also, the comparison between the literature results and our results is limited since older ages were not explored in earlier studies. One hypothesis to explain results could be due to late optimal sexual maturity in Indian red jungle fowls. The SQF is dependent on the quantitative parameters of semen and on one qualitative parameter, the number of morphologically normal and live spermatozoa. In the present study, the SQF was significantly higher at 43-54 months of age compared to other ages. As discussed earlier, the Indian red jungle fowl is a resident of Temperate and Tropical forest and developed a high tolerance to environmental variations that could be "cost- 
intensive" for the animal metabolism and consequently the sexual maturation. We suggest that the Indian red jungle fowl would get fully mature at later ages compared to other fowls [31].

Sperm motility was the only quality factor that was not affected by the age in the present study, partially confirming the results obtained by Sonseeda et al. [45] on Thai indigenous chicken of over 30 months. Sperm motility is a predictive parameter of viability and quality of semen. However, in the present study, this parameter did not follow the evolution of the viability measurements. This could indicate a specific reproductive maturation process where the different functions of the sperm do not reach the maturity at the same time; the signaling pathways and flagellar structures related to motility being fully mature much earlier than plasmatic membranes and acrosome attributes.

The sperm production, volume and concentration of sperm were higher in spring and low in the other seasons with a remarkably low semen volume in summer. The sperm production is highly species-specific and even varies among different strains or breeds [46], and may vary considerably throughout the year and seasons among avian species $[30,40]$. Environmental factors such as photoperiod and temperature affect semen production. In mild climates with large range of photoperiods/temperatures, domestic fowl sperm production is totally stopped for some months during autumn/winter and reaches maximum during spring. In subtropical desert and in Saharan climates with a smaller range of annual photoperiods, sperm production may be severely affected by the extremely hot temperatures and lack of precipitation of the summer $[30,56]$. These environmental cues have also been expressed in a breed specific manner. Some breeds show consistent semen production throughout the year as in Thai chicken held in tropical humid climates $[45,57,58]$.

Our study shows that the seasonal sperm production of Indian red jungle fowl is not so far from the Thai indigenous chicken "model", but also shows characteristics close to the 
"Saharan model" with summer variations potentially related to the high temperatures of the

Pakistan summer. Indeed, deleterious effects of high temperatures on germ cells have already been described [59]. The results of the present study are in agreement with previous studies on Northern pintail ducks and Nigerian local domestic chicken in which high summer temperatures caused temporary reduction in sperm production $[40,43,59]$. The low volume of semen in hot summer could tentatively be related to the absence of cutaneous heat evaporation that cannot mitigate the stressful events of heat disruption in summer season [60].

In our study, spring was identified as the best season for the SQF that mixes quantitative and viability sperm traits and for many other sperm quality traits (motility, viability, acrosome integrity). In mild climates, the lengthening of photoperiod in spring season acts as an environmental cue, stimulates the secretion of FSH, LH and testosterone, which play important role in spermatogenesis and semen production [61]. Photoperiod increase has previously been reported to increase the number of morphologically normal and live sperm as well as motility and SQF in domestic fowls such as free range poultry, Leghorns and others $[30,62,63]$. At the opposite, poor livability and viability of sperm in winter or autumn have directly been associated with the shortening of the photoperiod in freerange poultry [64] and turkey [53]. Poor motilities were also reported in correlation with loss of energy and mitochondrial integrity in shortened photoperiod compared to spring collected semen [65]. Seasonal differences in mitochondrial permeability [66] and its membrane phospholipids composition [67] could also contribute to explain the greater sensitivity of sperm in time of short photoperiod [64].

In the "Saharan climate," the semen quality of Nigerian shika brown in terms of live and normal sperm was reported maximum in winter season, which is in contrast to the present study [68]. The reason of these differences could possibly be attributed to heterogeneity of 
298

299

300

301

302

303

304

305

306

307

308

309

310

311

312

313

314

315

316

317

318

319

320

321

the semen quality among breeds, strains and species-specificity [47], but also to the specific

Saharan climate. The terrible dry and hot summer would have a significant role in the adaptation of the reproductive season, the best season of reproduction being consequently moved to winter. Regarding this parameter, the "Pakistan" environment of the Indian red jungle fowl presents a more classical but "mixed" seasonal effect since sperm production is present all over the year.

It is concluded that Indian red jungle fowls exhibit better semen quality in spring season and chronological increasing trend with maximal quality at the age of 43-54 months in terms of volume, sperm concentration, total sperm number per ejaculate, motility, viability, semen quality factor, plasma membrane and acrosome integrity. It is suggested that semen ejaculates of maximal quality can be achieved at the age of four years in the spring season. These elements are very important in order to build an AI program for the conservation of genetic diversity of the Indian red jungle fowl.

\section{References}

[1] Delacour J. The pheasants of the world. Country Life Ltd, London1951.

[2] Gautier Z. "Gallus gallus" (On-line), Animal Diversity Web 2002. Accessed May 31, 2016 at http://animaldiversity.org/accounts/Gallus_gallus/

[3] Eriksson J, Larson G, Gunnarsson U, Bedhom B, Tixier-Boichard M, Strömstedt L, Wright D, Jungerius A, Vereijken A, Randi E, Jensen P, Andersson LIdentification of the yellow skin gene reveals a hybrid origin of the domestic chicken. PloS Gen 2008;4: e1000010.

[4] IUCN (2015) IUCN Red list of threatened species 2015-4. http://www.iucnredlist.org/details/22679199/0. 
[5] Birdlife International (2016) Gallus gallus. The IUCN Red List of Threatened Species 2016: http://dx.doi.org/10.2305/IUCN.UK.2012-1.RLTS.T22679199A40112723.en.

[6] Wang LK, Hails CJ. An annotated checklist of birds of Singapore. Raffles BullZool 2007;15:1-179.

[7] Subhani A, Awan MS, Anwar M, Ali U, Dar NI. Population status and distribution pattern of red jungle fowl (Gallus gallus murghi) in Deva Vatala National Park, Azad Jammu \& Kashmir, Pakistan: A pioneer study. Pak J Zool 2010;42:701-706.

[8] Rakha BA, Ansari MS, Hussain I, Malik MF, Akhter S, Blesbois E. Semen characteristics of the Indian Red Jungle Fowl (Gallus gallus murghi). Eur J Wildl Res 2015a;61:379-386.

[9] Rakha BA, Hussain I, Malik MF, Akhter S, Ansari MS. Impact of ejaculate frequencies on the quality of Red Jungle Fowl (Gallus gallus murghi) semen. Avian Biol Res 2015b;8:109-112.

[10] Rakha BA, Ansari MS, Akhter S, Hussain I, Blesbois E. Cryopreservation of Indian red jungle fowl (Gallus gallus murghi) semen. Anim Reprod Sci 2016a;174:45-55.

[11] Peterson AT, Brisbin IL. Genetic endangerment of wild Red Jungle fowl Gallus gallus?. Bird Cons Int1998;8:387-394.

[12] Mukesh SKS, Shukla M, Sharma LK, Mohan N, Goyal SP, Sathyakumar S. Identification of galliformes through forensically informative nucleotide sequencing (FINS) and its implication in wildlife forensics. J Forensic Res 2013;4:195 doi:10.4172/2157-7145.1000195.

[13] Kumar V, Shukla SK, Mathew J, Sharma D. Genetic diversity and population structure analysis between Indian red jungle fowl and domestic chicken using microsatellite markers. Anim Biotech 2015;26:201-210. 
[14] Blanco JM, Gee G, Wildt DE, Donoghue AM. Species variation in osmotic, cryoprotectant, and cooling rate tolerance in poultry, eagle, and peregrine falcon spermatozoa. Biol Reprod 2000;63:1164-1171.

[15] Łukaszewicz E, Chrzanowska M, Jerysz A, Chełmońska B. Attempts on freezing

the $\quad$ Greylag (Anser anser L.) gander semen. Anim Reprod Sci 2004;80:163-173.

[16] Blesbois E, Seigneurin F, Grasseau I, Limouzin C, Besnard J, Gourichon D, TixierBoichard M. Semen cryopreservation for ex situ management of genetic diversity in chicken: creation of the French avian cryobank. Poul Sci 2007;86:555-564.

[17] Blesbois E, Grasseau I, Seigneurin F, Mignon-Grasteau S, Saint Jalme M, MialonRichard MM. Predictors of success of semen cryopreservation in chickens. Theriogenology2008;69:252-261.

[18] Blanco JM, Long JA, Gee G, Wildt DE, Donoghue AM Comparative cryopreservation of avian spermatozoa: benefits of non-permeating osmoprotectants and ATP on turkey and crane sperm cryosurvival. Anim Reprod Sci 2011;123:242-248.

[19] Blanco JM, Long JA, Gee G, Wildt DE, Donoghue AM. Comparative cryopreservation of avian spermatozoa: effects of freezing and thawing rates on turkey and sandhill crane sperm cryosurvival. Anim Reprod Sci 2012;131:1-8.

[20] Rakha BA, Hussain I, Akhter S, Ullah N, Andrabi SMH, Ansari MS. Evaluation of Tris-citric acid, skim milk and sodium citrate extenders for liquid storage of Punjab Urial (Ovis vignei punjabiensis) spermatozoa. Reprod Biol 2013;13:238-242.

[21] Holt WV. Basic aspects of frozen storage of semen. Anim Reprod Sci 2000;62:3-22.

[22] Blesbois E. Freezing avian semen. Avian Biol Res2011;4:52-58.

[23] Saacke RG. Semen quality in relation to semen preservation. J Dairy Sci $1983 ; 66: 2635-2644$. 
[24] Siudzińska A, Łukaszewicz E. Effect of semen extenders and storage time on sperm morphology of four chicken breeds. J Appl Poul Res 2008;17:101-108.

[25] Lierz M, Reinschmidt M, Müller H, Wink M, Neumann D. A novel method for semen collection and artificial insemination in large parrots (Psittaciformes). Sci Rep2013;3.

[26] Sexton KJ, Renden JA, Marple DN, Kempainen RJ. Effects of dietary energy on semen production, fertility, plasma testosterone, and carcass composition of broilerbreeder males in cages. Poul Sci1989;68:1688-1694.

[27] Anderson J.The semen of animals and its use for artificial insemination. Greenworld Publishers2001.

[28] Oguntunji AO, Aderemi FA, Lawal TE, Alabi OM. The influence of seasonal variation on performance of a commercial laying strain in a derived savanna environment in Nigeria. Nigerian Poul Sci J 2008;5:75-82.

[29] Ansari MS, Rakha BA, Andrabi SMH, Ullah N, Iqbal R, Holt WV, Akhter S. Glutathione-supplemented tris-citric acid extender improves the post-thaw quality and in vivo fertility of buffalo (Bubalus bubalis) bull spermatozoa. Reprod Biol 2012;12:271-276.

[30] Elagib HAA, Musharaf NA, Makawi SA, Mohamed HE. The effects of age and season on semen characteristics of white leghorn cocks under Sudan conditions. Int J Poult Sci 2012;11:47-49.

[31] Malik A, Haron AW, Yusoff R, Nesa M, Bukar M, Kasim A. Evaluation of the ejaculate quality of the red jungle fowl, domestic chicken, and bantam chicken in Malaysia. Turk J Vet Anim Sci2013;37:564-568.

[32] Burrows WH, Quinn JP. A method of obtaining spermatozoa from the domestic fowl. Poul Sci1935;14:251-253. 
[33] Rakha BA, Ansari MS, Hussain I, Anwar M, Akhter S, Blesbois E.Comparison of extenders for liquid storage of Indian red jungle fowl (Gallus gallus murghi) spermatozoa. Avian Biol Res 2016b;9:207-2012.

[34] Zemjanis R. Diagnostic and therapeutic technique in animal reproduction. Baltimore, Williams and Wilkins Company1970.

[35] De Reviers M, Williams J, Garreau M, Brillard JP. Predicting the adult dailysperm output after the first ejaculates in cockerels raised under different photoschedules. Reprod NutDévelop1981;21:1113-1124.

[36] Santiago-Moreno J, Castaño C, Coloma MA, Gómez-Brunet A, Toledano-Díaz A, López-Sebastián A, Campo JL. Use of the hypo-osmotic swelling test and aniline blue stainingtoimprove the evaluation of seasonal sperm variation in native Spanish freerange poultry. Poul Sci 2009;88:2661-2669.

[37] Bakst MR, Cecil HC. Determination of sperm concentration II. Establishing a standard curve. Techniques for semen evaluation, semen storage, and fertility determinationEd. Bakst MR, Cecil HC 1997;11-19.

[38] Jianzhong L, Yiling Z. Methods and effects of Hongshan cock spermatozoa cryopreservation. Wuhan Uni J Nat Sci2006;11:447-450.

[39] Santiago-Moreno J, Castaño C, Toledano-Díaz A, Esteso MC, López-Sebastián A, Gañán N, Blesbois E. Characterization of red-legged partridge (Alectoris rufa) sperm: seasonal changes and influence of genetic purity. Poul Sci2015;94:80-87.

[40] Bah GS, Chaudhari SUR, Al-Amin JD. Semen characteristics of local breeder cocks in the Sahel region of Nigeria. Revue ÉlevMéd Vét Trop 2001;54:153-158.

[41] Dumpala PR, Parker HM, McDaniel CD.The effect of semen storage temperature and diluent type on the sperm quality index of broiler breeder semen. Int J Poult Sci 2006;5:838-845. 
[42] Obidi JA, Onyeanusi BI, Rekwot PI, Ayo JO, Dzenda T. Seasonal variations in seminal characteristics of Shikabrown breeder cocks. Int J Poul Sci2008;7:1219-1223.

[43] Tabatabaei S, Chaji M, Mohammadabadi T. Correlation between age of rooster and semen quality in Iranian indigenous broiler breeder Chickens. J Anim Vet Adv 2010;9:195-198.

[44] Shanmugam M, Rajkumar U, Reddy MR, Rao SR. Effect of age on semen quality in naked neck and dwarf chicken under tropical climatic conditions. Anim Prod Sci 2012;52:964-968.

[45] Sonseeda P, Vongpralub T, Laopaiboon B. Effects of Environmental Factors, Ages and Breeds on Semen Characteristics in Thai Indigenous Chickens: A One-year Study. The Thai J Vet Med2013;43:347.

[46] Churchil RR, Praveena PE, Sharma D. Semen quality parameters, their interrelationship and post-washing sperm attributes of Rhode Island Red roosters. Vet World 2014;7: 1117-1122.

[47] Long JA, Bongalhardo DC, Pelaez J, Saxena S, Settar P, O’Sullivan NP, Fulton JE. Rooster semen cryopreservation: effect of pedigree line and male age on postthaw sperm function. Poul Sci2010;89:966-973.

[48] Chotesangasa R. Effects of mating ratio, cock number in the flock and breeder age on fertility in Thai native chicken flock. Nat Sci2001;35:122-131.

[49] Hafez B, Hafez ESE. Reproduction in Farm Animals. 7th ed. New York. Lippincott Williams and Wilkins, USA2000.

[50] Zavos PM, Graham EF. Effects of various degrees of supercooling and nucleation temperatures on fertility of frozen turkey spermatozoa. Cryobiol1983;20:553-559. 
[51] Daader AH, Seleem TST. Response of spermatozoa of different breeds of rabbits to hypo osmotic swelling test. In Proc: The $4^{\text {th }}$ Inter. Con. on Rabbit Prod. in Hot Clim., Sharm El-Sheikh, Egypt, 2005;177-181.

[52] Ramu S, Jeyendran RS. The hypo-osmotic swelling test for evaluation of sperm membrane integrity. Spermatogenesis: Methods and Protocols, 2013;21-25.

[53] Douard V, Hermier D, Magistrini M, Blesbois E. Reproductive period affects lipid composition and quality of fresh and stored spermatozoa in turkeys. Theriogenology 2003;59:753-764.

[54] Kelso KA, Cerolini S, Noble RC, Sparks NC, Speake BK. Lipid and antioxidant changes in semen of broiler fowl from 25 to 60 weeks of age. J Reprod Fertil 1996;106:201-206.

[55] Cerolini S, Kelso KA, Noble RC, Speake BK, Pizzi F, Cavalchini LG. Relationship between spermatozoan lipid composition and fertility during aging of chickens. Biol Reprod1997;57:976-980.

[56] Peltoniemi OAT, Love RJ, Heinonen M, Tuovinen V, Saloniemi H. Seasonal and management effects on fertility of the sow: a descriptive study. Anim Reprod Sci $1999 ; 55: 47-61$.

[57] Aengwanich W. Effects of high environmental temperature on blood indices of Thai indigenous chickens, thai indigenous chickens crossbred and broilers. Int J Poul Sci $2007 ; 6: 427-430$.

[58] Penfold LM, Wildt DE, Herzog TL, Lynch W, Ware L, Derrickson SE, Monfort SL. Seasonal patterns of LH, testosterone and semen quality in the Northern pintail duck (Anas acuta). Reprod Fertil Develop2001;12:229-235.

[59] Duangduen C, Duangjinda M, Katavatin S, Aeagwanich W. Effect of hsp70 Genotypes on Thermotolerance in Thai Native Chicken and Broilers. In Proceedings 
of the 4th Symposium on Thermotolerance in Domestic Animals. Khon Kaen. $2008 ; 241-245$.

[60] Bianca W. The signifiance of meteorology in animal production. Int $\mathrm{J}$ Biomet $1976 ; 20: 139-156$.

[61] Thurston RJ, Korn N. Spermiogenesis in commercial poultry species: anatomy and control. Poul Sci2000;79:1650-1668.

[62] Sexton TJ, Fewlass TA A New Poultry Semen Extender 2. Effect of the Diluent Components on the Fertilizing Capacity of Chicken Semen Stored at $5^{\circ}$ C. Poul Sci $1978 ; 57: 277-284$.

[63] Giesen AF, Sexton TJ. Beltsville poultry semen extender. 9. Effect of storage temperature on turkey semen held eighteen hours. Poul Sci1983;62:1305-1311.

[64] Santiago-Moreno J, Castaño C, Toledano-Díaz A, Coloma MA, López-Sebastián A, Prieto MT, Campo JL. Influence of Season on the Freezability of Free-Range Poultry Semen. Reprod Domest Anim 2012;47:578-583.

[65] Long JA. Avian semen cryopreservation: what are the biological challenges?. Poul Sci2006;85:232-236.

[66] Savina MV, Emelyanova LV, Belyaeva EA. Bioenergetic parameters of lamprey and frog liver mitochondria during metabolic depression and activity. Comparative Biochemistry and Physiology Part B: Biochemist Mol Biol2006;145:296-305.

[67] Martin N, Kraffe E, Guderley H. Effect of day length on oxidative capacities of mitochondria from red muscle of rainbow trout (Oncorhynchus mykiss). Comparative Biochemistry and Physiology Part A: Mol Integr Physiol2009;152:599-603.

[68] Rekwot PI, Abubakar YU, Anyam AA, Sekoni VO, Jatau J, Magaji S. Spermiogram of Rhode Island Red breeder cocks. In: Nigerian Veterinary Medical Association Conference. 2005;1-10. 
1 Table 1: Effect of season and age (Mean \pm SE) on quantitative efficiency of spermatogenesis in Indian red

2 jungle fowl: A 4-year retrospective study ( $\mathrm{n}=8$ cocks/1148ejaculates)

\begin{tabular}{llllll}
\hline \multicolumn{5}{c}{ Age in months } \\
\cline { 3 - 6 } & Season & $6-18$ & $19-30$ & $31-42$ & $43-54$ \\
\hline Semen volume $(\mu \mathrm{L})$ & Autumn & $41.9 \pm 5.1^{\mathrm{c}, \mathrm{z}}$ & $56.5 \pm 4.4^{\mathrm{b}, \mathrm{y}}$ & $68.0 \pm 7.5^{\mathrm{b}, \mathrm{y}}$ & $73.4 \pm 2.9^{\mathrm{c}, \mathrm{x}}$ \\
& Spring & $88.7 \pm 9.5^{\mathrm{a}, \mathrm{z}}$ & $78.5 \pm 7.6^{\mathrm{a}, \mathrm{y}}$ & $106.6 \pm 6.8^{\mathrm{a}, \mathrm{x}}$ & $160.1 \pm 8.2^{\mathrm{a}, \mathrm{w}}$ \\
& Summer & $25.3 \pm 4.3^{\mathrm{d}, \mathrm{z}}$ & $26.4 \pm 2.8^{\mathrm{d}, \mathrm{y}}$ & $25.6 \pm 1.9^{\mathrm{c}, \mathrm{x}}$ & $39.9 \pm 3.6^{\mathrm{d}, \mathrm{w}}$ \\
& Winter & $41.1 \pm 4.1^{\mathrm{b}, \mathrm{y}}$ & $44.2 \pm 2.9^{\mathrm{c}, \mathrm{y}}$ & $63.3 \pm 5.4^{\mathrm{b}, \mathrm{x}}$ & $93.8 \pm 4.2^{\mathrm{b}, \mathrm{w}}$ \\
\hline Sperm concentration & Autumn & $0.45 \pm 0.1^{\mathrm{b}, \mathrm{z}}$ & $0.95 \pm 0.2^{\mathrm{b}, \mathrm{y}}$ & $2.09 \pm 0.3^{\mathrm{a}, \mathrm{x}}$ & $3.00 \pm 0.2^{\mathrm{b}, \mathrm{w}}$ \\
$\left(1 \times 10^{9} \mathrm{~mL}^{-1}\right)$ & Spring & $1.11 \pm 0.2^{\mathrm{a}, \mathrm{z}}$ & $1.83 \pm 0.3^{\mathrm{a}, \mathrm{y}}$ & $2.50 \pm 0.2^{\mathrm{a}, \mathrm{x}}$ & $3.41 \pm 0.3^{\mathrm{a}, \mathrm{w}}$ \\
& Summer & $0.86 \pm 0.2^{\mathrm{a}, \mathrm{z}}$ & $0.91 \pm 0.1^{\mathrm{b}, \mathrm{y}}$ & $2.00 \pm 0.3^{\mathrm{a}, \mathrm{x}}$ & $2.54 \pm 0.1^{\mathrm{b}, \mathrm{w}}$ \\
\hline Total sperm per & Winter & $0.53 \pm 0.1^{\mathrm{b}, \mathrm{z}}$ & $1.14 \pm 0.1^{\mathrm{b}, \mathrm{y}}$ & $2.37 \pm 0.2^{\mathrm{a}, \mathrm{x}}$ & $3.01 \pm 0.2^{\mathrm{b}, \mathrm{w}}$ \\
ejaculate $\left(1 \mathrm{x} 10^{9}\right)$ & Autumn & $0.03 \mathrm{~b}, \mathrm{y}$ & $0.06 \mathrm{~b}, \mathrm{y}$ & $0.14 \mathrm{~b}, \mathrm{x}$ & $0.22 \mathrm{~b}, \mathrm{w}$ \\
& Spring & $0.12 \mathrm{a}, \mathrm{z}$ & $0.15 \mathrm{a}, \mathrm{y}$ & $0.21 \mathrm{a}, \mathrm{x}$ & $0.37 \mathrm{a}, \mathrm{w}$ \\
& Summer & $0.02 \mathrm{~b}, \mathrm{x}$ & $0.04 \mathrm{~b}, \mathrm{x}$ & $0.07 \mathrm{~b}, \mathrm{x}$ & $0.13 \mathrm{c}, \mathrm{w}$ \\
& Winter & $0.02 \mathrm{~b}, \mathrm{y}$ & $0.04 \mathrm{~b}, \mathrm{y}$ & $0.14 \mathrm{~b}, \mathrm{x}$ & $0.25 \mathrm{~b}, \mathrm{w}$ \\
\hline
\end{tabular}

3 The values (mean \pm SE) for a given semen parameter in a column (season $=a, b, c$, and d) and

4 row (age $=\mathrm{w}, \mathrm{x}, \mathrm{y}$ and $\mathrm{z}$ ) with different superscript differ significantly $(\mathrm{P}<0.05)$. 


\begin{tabular}{|c|c|c|c|c|c|}
\hline & \multirow[b]{2}{*}{ Season } & \multicolumn{4}{|c|}{ Age in months } \\
\hline & & $6-18$ & $19-30$ & $31-42$ & $43-54$ \\
\hline \multirow[t]{4}{*}{ Sperm motility (\%) } & Autumn & $74.8 \pm 1.7^{\mathrm{b}, \mathrm{x}}$ & $75.7 \pm 1.7^{b, x}$ & $76.9 \pm 2.9^{b, x}$ & $82.7 \pm 3.4^{\mathrm{a}, \mathrm{x}}$ \\
\hline & Spring & $77.8 \pm 2.4^{\mathrm{a}, \mathrm{y}}$ & $82.1 \pm 2.7^{\mathrm{a}, \mathrm{y}}$ & $83.9 \pm 5.0^{\mathrm{a}, \mathrm{y}}$ & $88.9 \pm 1.8^{\mathrm{a}, \mathrm{x}}$ \\
\hline & Summer & $61.9 \pm 2.2^{\mathrm{c}, \mathrm{x}}$ & $66.8 \pm 2.2^{c, x}$ & $71.5 \pm 4.4^{\mathrm{b}, \mathrm{x}}$ & $78.0 \pm 4.8^{\mathrm{b}, \mathrm{x}}$ \\
\hline & Winter & $36.0 \pm 1.1^{\mathrm{d}, \mathrm{z}}$ & $42.1 \pm 5.5^{\mathrm{d}, \mathrm{y}}$ & $46.9 \pm 3.4^{\mathrm{c}, \mathrm{y}}$ & $58.8 \pm 3.1^{\mathrm{c}, \mathrm{x}}$ \\
\hline \multirow{4}{*}{$\begin{array}{l}\text { Sperm plasma } \\
\text { membrane } \\
\text { integrity }(\%)\end{array}$} & Autumn & $16.7 \pm 1.9^{b, z}$ & $27.3 \pm 3.0^{\mathrm{c}, \mathrm{y}}$ & $48.3 \pm 5.1^{b, x}$ & $84.7 \pm 1.3^{\mathrm{c}, \mathrm{w}}$ \\
\hline & Spring & $44.0 \pm 3.4^{\mathrm{a}, \mathrm{y}}$ & $45.8 \pm 3.8^{\mathrm{a}, \mathrm{y}}$ & $56.9 \pm 2.8^{\mathrm{a}, \mathrm{x}}$ & $95.3 \pm 1.5^{\mathrm{a}, \mathrm{w}}$ \\
\hline & Summer & $21.3 \pm 1.8^{\mathrm{b}, \mathrm{z}}$ & $29.5 \pm 4.1^{\mathrm{c}, \mathrm{y}}$ & $44.9 \pm 3.5^{\mathrm{b}, \mathrm{x}}$ & $90.9 \pm 0.8^{\mathrm{b}, \mathrm{w}}$ \\
\hline & winter & $17.8 \pm 2.4^{\mathrm{b}, \mathrm{z}}$ & $38.1 \pm 3.9^{\mathrm{b}, \mathrm{y}}$ & $47.7 \pm 6.7^{\mathrm{b}, \mathrm{x}}$ & $67.8 \pm 4.4^{\mathrm{d}, \mathrm{w}}$ \\
\hline \multirow[t]{4}{*}{ Sperm livability (\%) } & Autumn & $19.9 \pm 3.1^{b, z}$ & $39.6 \pm 7.0^{b, y}$ & $51.4 \pm 2.9^{\mathrm{b}, \mathrm{x}}$ & $66.1 \pm 5.6^{b, \mathrm{w}}$ \\
\hline & Spring & $61.9 \pm 6.0^{\mathrm{a}, \mathrm{y}}$ & $69.5 \pm 4.3^{\mathrm{a}, \mathrm{y}}$ & $84.7 \pm 1.5^{\mathrm{a}, \mathrm{x}}$ & $88.6 \pm 1.7^{\mathrm{a}, \mathrm{w}}$ \\
\hline & Summer & $26.8 \pm 4.4^{\mathrm{b}, \mathrm{y}}$ & $28.0 \pm 4.7^{\mathrm{b}, \mathrm{y}}$ & $43.6 \pm 5.0^{\mathrm{b}, \mathrm{x}}$ & $90.3 \pm 0.9^{\mathrm{a}, \mathrm{w}}$ \\
\hline & winter & $23.9 \pm 3.0^{\mathrm{b}, \mathrm{z}}$ & $31.3 \pm 4.6^{\mathrm{b}, \mathrm{y}}$ & $44.2 \pm 5.9^{\mathrm{b}, \mathrm{x}}$ & $66.0 \pm 4.7^{\mathrm{b}, \mathrm{w}}$ \\
\hline \multirow{4}{*}{$\begin{array}{l}\text { Sperm acrosomal } \\
\text { integrity }(\%)\end{array}$} & Autumn & $48.7 \pm 7.2^{\mathrm{a}, \mathrm{x}}$ & $54.9 \pm 7.1^{x}$ & $51.7 \pm 6.5^{x}$ & $74.9 \pm 2.3^{\mathrm{w}}$ \\
\hline & Spring & $52.8 \pm 4.6^{\mathrm{a}, \mathrm{y}}$ & $64.4 \pm 4.2^{\mathrm{x}}$ & $51.7 \pm 4.4^{y}$ & $79.5 \pm 1.4^{\mathrm{w}}$ \\
\hline & Summer & $17.8 \pm 2.7^{\mathrm{c}, \mathrm{z}}$ & $57.1 \pm 6.3^{\mathrm{x}}$ & $51.0 \pm 4.5^{\mathrm{y}}$ & $73.9 \pm 2.8^{\mathrm{w}}$ \\
\hline & winter & $41.9 \pm 3.7^{\mathrm{b}, \mathrm{x}}$ & $47.3 \pm 5.6^{\mathrm{x}}$ & $47.5 \pm 7.0^{\mathrm{x}}$ & $75.1 \pm 2.9^{w}$ \\
\hline \multirow[t]{4}{*}{ Semen quality factor } & Autumn & $25.4 \pm 11.3^{\mathrm{b}, \mathrm{z}}$ & $22.0 \pm 7.1 b, y$ & $71.6 \pm 10.3^{b, x}$ & $143.5 \pm 11.7^{\mathrm{c}, \mathrm{w}}$ \\
\hline & Spring & $81.8 \pm 18.0^{\mathrm{a}, \mathrm{z}}$ & $109.0 \pm 26.8^{\mathrm{a}, \mathrm{y}}$ & $179.6 \pm 36.0^{\mathrm{a}, \mathrm{x}}$ & $326.4 \pm 26.9^{\mathrm{a}, \mathrm{w}}$ \\
\hline & Summer & $6.2 \pm 1.6^{\mathrm{c}, \mathrm{z}}$ & $7.0 \pm 1.3^{\mathrm{d}, \mathrm{y}}$ & $17.5 \pm 2.4^{\mathrm{c}, \mathrm{x}}$ & $122.2 \pm 16.5^{\mathrm{d}, \mathrm{w}}$ \\
\hline & winter & $6.3 \pm 1.2^{\mathrm{c}, \mathrm{z}}$ & $14.1 \pm 2.6^{\mathrm{c}, \mathrm{y}}$ & $64.2 \pm 10.1^{\mathrm{b}, \mathrm{x}}$ & $168.0 \pm 14.2^{\mathrm{b}, \mathrm{w}}$ \\
\hline
\end{tabular}

The values (mean $\pm \mathrm{SE}$ ) for a given semen parameter in a column (season $=\mathrm{a}, \mathrm{b}, \mathrm{c}$, and d) and

Table 2: Effect of season and age (Mean \pm SE) on qualitative semen parameters in Indian red jungle fowl:

A 4-year retrospective study ( $\mathrm{n}=8$ cocks/ 1148 ejaculates)

row (age $=\mathrm{w}, \mathrm{x}, \mathrm{y}$ and $\mathrm{z})$ with different superscript differ significantly $(\mathrm{P}<0.05)$. 


\section{HIGHLIGHTS}

- Retrospective seminal parameters with respect to age/season of Indian red jungle fowl (IJRF) were studied over the 4-year period.

- Semen quantitative and qualitative traits increased with the increasing age.

- Spring was the best season for the production of high quality ejaculate at 4-years of age.

- The reproductive potential of IJRF is highly variable in many points from its descendants. 